\title{
ANTIBACTERIAL ACTIVITY OF FOUR MOUTHRINSES CONTAINING TRICLOSAN AGAINST SALIVARY STAPHYLOCOCCUS AUREUS
}

\author{
Juliane Maria Guerreiro Tanomaru; Andresa Piacezzi Nascimento²; Evandro Watanabe²; Fumio Matoba-Júnior ${ }^{3}$; \\ Mário Tanomaru-Filho'; ${ }^{1}$ zabel Yoko Ito
}

${ }^{1}$ Departamento de Odontologia Restauradora, Faculdade de Odontologia de Araraquara, Universidade Estadual Paulista, Araraquara, SP, Brasil; ${ }^{2}$ Departamento de Microbiologia, Faculdade de Ciências Farmacêuticas de Ribeirão Preto, Universidade de São Paulo, Ribeirão Preto, SP, Brasil; ${ }^{3}$ Departamento de Clínica Infantil, Faculdade de Odontologia de Ribeirão Preto, Universidade de São Paulo, Ribeirão Preto, SP, Brasil

Submitted: July 03, 2007; Returned to authors for corrections: February 01, 2008; Approved: July 06, 2008.

\begin{abstract}
The maximum inhibitory dilution (MID) of triclosan-based mouthwashes against 28 Staphylococcus aureus strains was evaluated. Dilutions ranging from 1/10 to 1/655,360 were prepared. Strains were inoculated using a Steers multipoint inoculator. The MID was considered as the maximum dilution capable of inhibiting microorganism growth. The mouthwashes presented different MIDs.
\end{abstract}

Key-words: microorganism, bacteria, mouthwash, triclosan.

Triclosan has been used for over 30 years in skincare products, such as soaps, deodorants, and creams. In dentistry, it was first used in an European toothpaste in 1985 (6). Today, triclosan is the active ingredient in many oral hygiene formulations.

McMurry et al. (9) demonstrated in a study with Escherichia coli that the antiseptic activity of triclosan is due to its ability to block the synthesis of fatty acids by inhibiting the enoylacyl carrier protein reductase enzyme. Aiming to increase its efficacy, triclosan has been associated to other substances, such as zinc citrate, a complementary antimicrobial agent (2). Saxton (13) demonstrated in vivo that a toothpaste containing $1 \%$ zinc citrate and $0.5 \%$ triclosan resulted in greater plaque inhibition than products containing zinc citrate or triclosan alone. Triclosan combined with methylvinyl ether/maleic acid (PVM/ MA) copolymer is also more efficacious in controlling dental plaque and caries in both in vivo and in vitro studies (10).

Staphylococcus aureus is a major human pathogen, responsible for a number of hospital-acquired infections (8). This microorganism is able to colonize several locations in the human body, but the mouth and hands are the main reservoirs for propagation of this germ in the hospital environment $(7,11)$.
Therefore, control of Staphylococcus aureus is extremely relevant for the determination of the antiseptic properties of hygiene products.

The goal of this study was to determine the maximum inhibitory dilution (MID) in vitro of four triclosan-based mouthwashes against 28 Staphylococcus aureus field strains using the agar dilution method.

Four triclosan-based mouthrinses were evaluated (Table 1). Determination of the MID was performed in duplicate by double serial dilution (from $1 / 10$ through $1 / 655,360$ ) in test tubes $(20 \times 200 \mathrm{~mm})$ with $2.0 \mathrm{ml}$ of sterile distilled water. After dilutions were made, $18.0 \mathrm{ml}$ of Mueller Hinton Agar culture medium (Difco ${ }^{\circledR}$ ) were added to each tube, and the resulting solutions were poured onto Petri dishes $(20 \times 100 \mathrm{~mm})$.

The microbial inoculum $\left(\sim 10^{8} \mathrm{CFU} / \mathrm{mL}\right)$ with turbidity equivalent to a McFarland standard of 0.5 was prepared in test tubes $(15 \times 125 \mathrm{~mm})$ with saline, using $28 \mathrm{~S}$. aureus field strains obtained from nasal and oral cavities. The strains were conserved on a collection cultured on $\mathrm{Ni}$ agar medium (5). The identification of $S$. aureus was based on the production of catalase and coagulase. Regardless results for coagulase test, all catalase positive Gram positive cocci were submitted to the

*Corresponding Author. Mailing address: Rua Humaitá, 1901- apto. 182, Centro, Cep: 14801-385 - Araraquara, SP, Brasil. Phone +55-16-3336-4658, Fax.+55-16-3336-4658. E-mail: jutanomaru@uol.com.br 
Table 1. Composition and manufacturers of the mouthrinses evaluated.

\begin{tabular}{|c|c|c|}
\hline Mouthrinses & \multicolumn{2}{|c|}{ Composition } \\
\hline $\begin{array}{c}\text { Sanifill }{ }^{\circledR} \text { Ação Total } \\
\text { (Facilit Odontológica e Perfumaria } \\
\text { LTDA, Brazil) }\end{array}$ & $\begin{array}{l}\text { - Sodium fluoride } 0.05 \% \\
\text { ( } 226 \mathrm{ppm} \text { fluoride ion) } \\
\text { - Sorbitol } 70 \% \\
\text { - Methylparaben } \\
\text { - Triclosan } \\
\text { - Cetyl pyridinium chloride }\end{array}$ & $\begin{array}{l}\text { - Sodium saccharin } \\
\text { - Sodium lauryl sulphate } \\
\text { - Ethanol } \\
\text { - Mint flavor } \\
\text { - Cl42090 } \\
\text { - Cl19140 } \\
\text { - Deionized water }\end{array}$ \\
\hline $\begin{array}{l}\text { Malvatricin }{ }^{\circledR} \text { Plus (Laboratório } \\
\text { Daudt Oliveira LTDA, Brazil) }\end{array}$ & $\begin{array}{l}\text { - Benzoic acid } \\
\text { - Zinc chloride } \\
\text { - Methyl vinyl ether-co-maleic } \\
\text { anhydride copolymer } \\
\text { - EDTA- Malva sylvestris L. } \\
\text { - Sodium monofluorophosphate } \\
\text { (225ppm fluoride) } \\
\text { - Hydrogenated castor oil }\end{array}$ & $\begin{array}{l}\text { - Poloxamer } 407 \\
\text { - Sodium saccharin } \\
\text { - Sorbitol } \\
\text { - Triclosan }(0.03 \%) \\
\text { - Xylitol } \\
\text { - Cl42090 } \\
\text { - Cl47005 } \\
\text { - Flavoring agents } \\
\text { - Demineralized water }\end{array}$ \\
\hline $\begin{array}{l}\text { Malvatrici }{ }^{\circledR} \text { Branqueador } \\
\text { (Laboratório Daudt Oliveira } \\
\text { LTDA, Brazil) }\end{array}$ & $\begin{array}{l}\text { - Phosphoric acid } \\
\text { - Titanium dioxide } \\
\text { - Eucalyptol } \\
\text { - Sodium fluoride (225ppm fluoride) } \\
\text { - Glycerin } \\
\text { - Malva sylvestris } L .\end{array}$ & $\begin{array}{l}\text { - Methylparaben } \\
\text { - Mint oil } \\
\text { - Sodium perborate } \\
\text { - Hydrogen peroxide } \\
\text { - Sorbitol } \\
\text { - Triclosan }(0.03 \%) \\
\text { - Flavoring agents } \\
\text { - Demineralized water }\end{array}$ \\
\hline $\begin{array}{c}\operatorname{Plax}^{\circledR} \text { (Colgate-Palmolive - } \\
\text { Indústria e Comércio LTDA, Brazil) }\end{array}$ & $\begin{array}{l}\text { - Ethanol } \\
\text { - PVM/MA copolymer }(0.20 \%) \\
\text { - Sodium fluoride }(227 \mathrm{ppm} \text { fluoride) } \\
\text { - Disodium phosphate } \\
\text { - Glycerin } \\
\text { - Sodium hydroxide }\end{array}$ & $\begin{array}{l}\text { - Sodium lauryl sulphate } \\
\text { - Sodium methyl taurate } \\
\text { - Sodium saccharin } \\
\text { - Sorbitol } \\
\text { - Triclosan }(0.03 \%) \\
\text { - Red CI } 16035 \\
\text { - Flavoring agents } \\
\text { - Water }\end{array}$ \\
\hline
\end{tabular}

API-Staph system (bioMérieux, France) for biochemical identification.

Microorganisms were seeded using a Steers multipoint inoculator (17). The Steers inoculator consists of two metallic plates: one of these plates has 25 wells onto which $200.0 \mu$ of each standardized microbial inoculum were transferred. The other plate has 25 metallic needles that fit into the wells. Using these needles, the inocula were seeded onto the surface of the culture medium in Petri dishes containing different dilutions of the mouthwashes. Since the Steers inoculator has 25 wells and 28 strains were evaluated, three inocula $(5.0 \mu \mathrm{L})$ were seeded equidistantly from each other, approximately one centimeter from the periphery of each Petri dish, using an automatic pipette.
The dishes were then incubated at $37^{\circ} \mathrm{C}$ for 24 hours, and readings were performed considering the MID as the greatest dilution of mouthwash capable of inhibiting growth of all the strains evaluated, following the methodology by Wade \& Addy (18). The examiners were calibrated and were blinded to the groups being evaluated.

Results were expressed as scores determined from minimum to maximum dilution and comparison between all groups was performed using the Kruskal-Wallis's nonparametric test. When this test showed significant difference between the groups, the Dunn's multiple comparison test, which allows two-by-two comparison between groups, was applied. The significance level used for the statistical testing was $5 \%(\mathrm{p}<0.05)$. 
The mouthwashes evaluated presented different MIDs (Fig. 1). Statistical analysis demonstrated significant difference among the four products evaluated $(\mathrm{p}<0.05)$, with $\mathrm{Plax}^{\circledR}$ being the most efficacious $(p<0.001)$. Sanifill ${ }^{\circledR}$ Ação Total was the least efficacious $(p<0.001)$. No significant difference was observed between Malvatricin ${ }^{\circledR}$ Plus and Malvatricin ${ }^{\circledR}$ Branqueador $(\mathrm{p}>0.05)$.

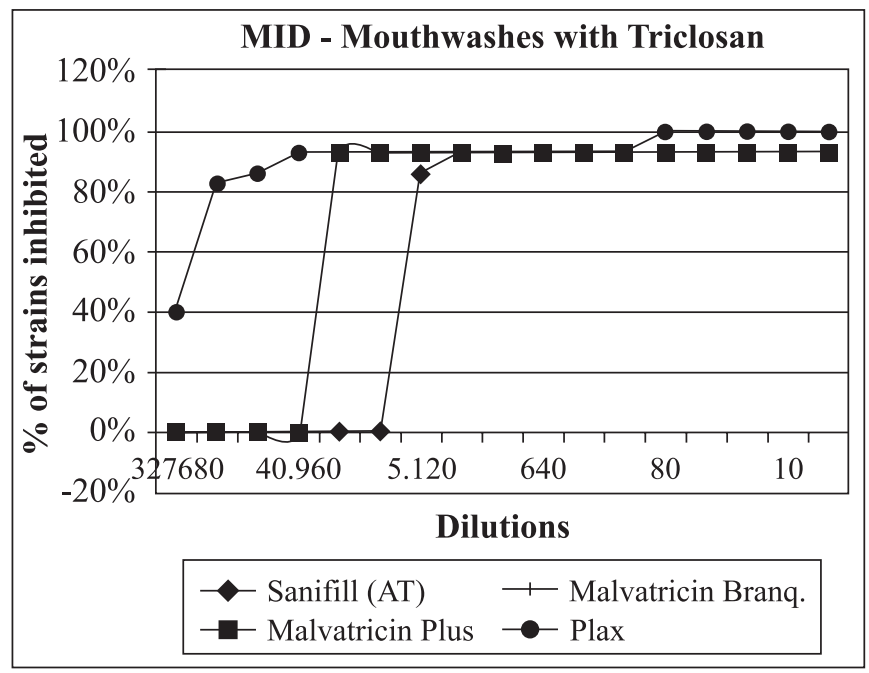

Figure 1. Graph depicting MID values obtained for each solution evaluated.

Plax ${ }^{\circledR}$ contains $0.03 \%$ triclosan with sodium fluoride $(225 \mathrm{ppm}$ fluoride) and $0.20 \%$ methylvinyl ether/maleic acid (PVM/MA) copolymer as active ingredients. The presence of PVM/MA may explain the better performance of Plax ${ }^{\circledR}$ compared to both Sanifill ${ }^{\mathbb{R}}$ Ação Total and Malvatricin ${ }^{\circledR}$ Branqueador, which do not include the polymer. Nabi et al. (10) demonstrated that the PVM/MA polymer increased the antibacterial activity of solutions containing triclosan.

Another polymer was evaluated by Singh et al. (15), who tested, in vivo, a mouthwash containing $0.03 \%$ triclosan and $0.25 \%$ copolymer of methoxyethylene and maleic acid. This formulation resulted in $31.03 \%$ reduction in plaque formation compared to a placebo mouthwash. In an in vivo study, Sreenivasan et al. (16) demonstrated that a mouthwash containing $0.03 \%$ triclosan and copolymer significantly reduced the number of the oral bacteria evaluated in comparison with placebo.

Sanifill ${ }^{\circledR}$ Ação Total contains triclosan and cetylpyridinium chloride (CPC) in its formulation. CPC is an antimicrobial agent widely employed in mouthrinse formulations $(12,19)$. The manufacturer of Sanifill ${ }^{\circledR}$ Ação Total does not provide information regarding the percentage of triclosan and CPC present in its composition. This combination did not improve the antimicrobial activity of the product, since this mouthwash presented the lower inhibition values according to the results of the present study. In spite of the inferior results, it is not possible to categorically affirm that Sanifill is the least effective mouthrinse because clinical evaluations may be influenced by the cumulative effect of inhibition of the microorganism and alteration of its capacity to adhere and form biofilm after continuous use of the solution.

Albuquerque $\mathrm{Jr}$ et al. (1), evaluated the MID for $\mathrm{Cepacol}^{\circledR}$, a mouthwash containing $0.05 \% \mathrm{CPC}$. This product inhibited 25 S. aureus strains when diluted at up to $1 / 20$. In the present study, Sanifill ${ }^{\circledR}$ Ação Total inhibited all 28 S. aureus strains up to $1 / 80$ dilution. These results demonstrate that the combination of triclosan and CPC improves the efficacy of the mouthwash.

Malvatricin ${ }^{\circledR}$ Plus has $0.03 \%$ triclosan and sodium monofluorophosphate (225 ppm fluoride) in its formulation. In addition to these active ingredients, it also contains methylvinyl ether/maleic acid (PVM/MA) copolymer. The lower efficacy of Malvatricin ${ }^{\circledR}$ Plus compared to Plax ${ }^{\circledR}$ may be due to the presence of ethanol in Plax ${ }^{\circledR}$, which may contribute for its antimicrobial action. Herrera et al. (4) evaluated the antimicrobial activity of four commercially available mouthrinses, three containing $0.12 \%$ chlorhexidine (one containing alcohol and two alcohol-free) and one product containing $0.12 \%$ chlorhexidine and $0.05 \%$ CPC (alcohol-free). It was observed that the product containing alcohol was more effective than the alcohol-free rinses, except for the formulation including chlorhexidine and CPC, which presented greater antimicrobial activity.

When Malvatricin ${ }^{\circledR}$ Plus was evaluated in the present study, two $S$. aureus strains grew, even at the minimum dilution used, 1/10. Fan et al. (3) demonstrated that the high MICs of triclosan occurred for $S$. aureus strains that overexpress the fabI gene, which codifies the enoyl-acyl carrier protein reductase, the target of triclosan. Furthermore, these authors demonstrated that the highest MICs (1 to $2 \mathrm{mg} / \mathrm{l}$ ) occurred for strains presenting mutations in the $f a b I$ gene. Therefore, bacterial resistance to triclosan may occur due to multiple mechanisms, such as target mutations, increased target expression, active efflux from the cell, and enzymatic inactivation/degradation (14).

Malvatricin ${ }^{\circledR}$ Branqueador, similarly to Malvatricin ${ }^{\circledR}$ Plus, contains $0.03 \%$ triclosan, but its composition does not include the copolymer. Even with this variation in composition, both presented similar activity, with no statistically significant differences. Malvatricin ${ }^{\circledR}$ Branqueador probably includes antimicrobial ingredients which are not present in Malvatricin ${ }^{\circledR}$ Plus.

The results of the present study demonstrated that various mouthrinses listing triclosan as the active ingredient presented different MIDs. This is probably due to the different formulations including associations with other active 
ingredients, such as copolymers, fluoride, CPC, and ethanol. It is assumed that the active product concentration and its interactions with other substances, in addition to differences in the formulations, would be responsible for different effects.

\section{RESUMO}

\section{Atividade antibacteriana de quatro anti-sépticos bucais contendo triclosan contra Staphylococcus aureus da saliva}

A Diluição Inibitória Máxima (DIM) de anti-sépticos bucais à base de triclosan contra 28 cepas de Staphylococcus aureus foi avaliada. Diluições de 1/10 a 1/655.360 foram preparadas. As cepas foram inoculadas com inoculador multipontual Steers. A DIM foi a maior diluição do anti-séptico que inibiu crescimento microbiano. Os anti-sépticos apresentaram diferentes DIMs.

Palavras-chave: microrganismos, bactéria, anti-sépticos, triclosan

\section{REFERENCES}

1. Albuquerque-Júnior, R.F.; Head, T.W.; Mian, H.; Rodrigo, A.; Müller, K.; Sanches, K.; Ito, I.Y. (2004). Reduction of salivary S. aureus and mutans group streptococci by a preprocedural chlorhexidine rinse and maximal inhibitory dilutions of chlorhexidine and cetylpyridinium. Quintessence Int., 35 (8), 635-640.

2. Bradshaw, D.J.; Marsh, P.D.; Watson, G.K.; Cummins, D. (1993). The effects of triclosan and zinc citrate, alone and in combination, on a community of oral bacteria grown in vitro. J. Dent. Res., 72 (1), 25-30.

3. Fan, F.; Yan, K.; Wallis, N.G.; Reed, S.; Moore, T.D.; Rittenhouse, S.F.; De Wolf, W.E.Jr.; Huang, J.; McDevitt, D.; Miller, W.H.; Seefeld, M.A.; Newlander, K.A.; Jakas, D.R.; Head, M.S.; Payne, D.J. (2002). Defining and combating the mechanisms of triclosan resistance in clinical isolates of Staphylococcus aureus. Antimicrob. Agents Chemother., 46 (11), 3343-3347.

4. Herrera, D.; Roldán, S.; Santacruz, I.; Santos, S.; Masdevall, M.; Sanz, M. (2003). Differences in antimicrobial activity of four commercial $0.12 \%$ chlorhexidine mouthrinse formulations: an in vitro contact test and salivary bacterial counts study. J. Clin. Periodontol., 30 (4), 307-314.

5. Ito, I.Y.; Costa, A.; Baracchini, O. (1969). Emprego da gema de ovo no siolamento de Staphylococcus aureus. An. Microbiol., 16, 189192.

6. Jones, R.D.; Jampani, H.B.; Newman, J.L.; Lee, A. (2000). Triclosan: a review of effectiveness and safety in health care settings. Am. J. Infect. Control., 28 (2), 184-196.

7. Knighton, H.T. (1960). Study of bacteriophage types and antibiotic resistance of Staphylococci isolated from dental students and faculty members. J. Dent. Res., 39, 906-911.

8. Lowy, F.D. (1998). Staphylococcus aureus infections. N. Engl. J. Med., 339 (8), 520-532.

9. McMurry, L.M.; Oethinger, M.; Levy, S.B. (1998). Triclosan targets lipid synthesis. Nature, 394, 531-532.

10. Nabi, N.; Mukerjee, C.; Schmid, R.; Gaffar, A. (1989). In vitro and in vivo studies on triclosan/PVM/MA copolymer/NaF combination as an anti-plaque agent. Am. J. Dent., 2, 197-206.

11. Piochi, B.J.; Zelante, F. (1975). Contribution to the study of Staphylococcus isolated in the mouth. III. Staphylococcus isolated from dental plaque. Rev. Fac. Odontol. São Paulo, 13 (1), 91-97.

12. Pizzo, G.; Guiglia, R.; Imburgia, M.; Pizzo, I.; D’Angelo, M.; Giuliana, G. (2006). The effects of antimicrobial sprays and mouthrinses on supragingival plaque regrowth: a comparative study. J. Periodontol., 77 (2), 248-256

13. Saxton, C.A. (1986). The effects of a dentifrice containing zinc citrate and 2,4,4' trichloro-2'-hydroxydiphenyl ether. J. Periodontol., 57 (9), 555-561.

14. Schweizer, H.P. (2001). Triclosan: a widely used biocide and its link to antibiotics. FEMS Microbiol. Lett., 202, 1-7.

15. Singh, S.M.; Rustogi, K.N.; Volpe, A.R.; Petrone, D.M.; Robinson, RS. (1990). Effect of a mouthrinse containing triclosan and a copolymer on plaque formation in a normal oral hygiene regimen. Am. J. Dent., 3, 563-565.

16. Sreenivasan, P.K.; Mattai, J.; Nabi, N.; Xu, T.; Gaffar, A. (2004). A simple approach to examine early oral microbial biofilm formation and the effects of treatments. Oral Microbiol. Immunol., 19, 297302.

17. Steers, E.; Foltz, E.L.; Graves, V.S. (1959). An inocula replicating apparatus for routine testing of bacterial susceptibility to antibiotics. Antibiot. Chemother., 9, 307-311.

18. Wade, W.G.; Addy, M. (1992). Antibacterial activity of some triclosancontaining toothpastes and their ingredients. J. Periodontol., 63 (4), 280-282.

19. Zimmer, S.; Kolbe, C.; Kaiser, G.; Krage, T.; Ommerborn, M.; Barthel, C. (2006). Clinical efficacy of flossing versus use of antimicrobial rinses. J. Periodontol., 77 (8), 1380-5. 